\title{
Calonectria metrosideri, a highly aggressive pathogen causing leaf blight, root rot, and wilt of Metrosideros spp. in Brazil
}

\author{
By R. F. Alfenas ${ }^{1,4}$, O. L. Pereira ${ }^{1,5}$, M. A. Ferreira ${ }^{2}$, V. L. Jorge ${ }^{1}$, P. W. Crous $^{3}$ and A. C. Alfenas ${ }^{1}$ \\ ${ }^{1}$ Department of Plant Pathology, Universidade Federal de Viçosa, Viçosa 36570-000, MG Brazil; ${ }^{2}$ Department of Plant Pathology, \\ Universidade Federal de Lavras, Lavras 37200-000, MG Brazil; ${ }^{3}$ CBS-KNAW Fungal Biodiversity Centre, Utrecht 3584 CT, The Netherlands; \\ ${ }^{4}$ Clonar Resistência a Doenças Florestais, CENTEV, Viçosa 36570-000, MG Brazil; \\ ${ }^{5}$ E-mail: oliparini@ufv.br (for correspondence)
}

\begin{abstract}
Summary
The genus Metrosideros includes several tree, shrub and vine species, native to the Pacific Islands. Seedlings from 25 seed lots of Metrosideros polymorpha and two seed lots of $M$. tremuloides with symptoms of root rot, stem girdling, wilting and round, purple leaf spots were observed in the Forestry Nursery at the Universidade Federal de Viçosa, Brazil. In the original disease site, seedling mortality reached up to $71 \%$ in M. polymorpha and $34 \%$ in M. tremuloides. Single conidial cultures obtained from infected leaf, root and stem samples of $M$. polymorpha were used to identify the fungal species. Morphological characters and DNA sequences of four loci, containing partial sequences of $\beta$-tubulin (TUB2), histone H3 (HIS3), calmodulin (CAL) and the elongation factor (tef-1 $\alpha$ ) genes of three isolates, indicated that they belong to a new species, described here as Calonectria metrosideri sp. nov. Potting medium infestation and inoculation of seedlings of $M$. polymorpha with an inoculum suspension at $1 \times 10^{4}$ conidia $\mathrm{ml}^{-1}$ induced typical symptoms of the disease (leaf spots, root rot and wilt), similar to those observed under natural conditions. Calonectria metrosideri was re-isolated, which fulfilled Koch's postulates, and confirmed its status as a pathogen.
\end{abstract}

\section{Introduction}

Metrosideros is a genus that includes several tree, shrub and vine species native to the Pacific Islands from the Philippines to New Zealand. Metrosideros polymorpha Gaudich, popularly known as ohia (Fig. 1) is the species dominant in Hawaiian ecosystems, occupying a wide variety of habitats (Cordell et al. 1998). This species and others of this genus can be used for medicinal purposes, wood production for energy, poles and several other uses (Friday and Herbert 2006).

In Hawaii, approximately $80 \%$ of native forests are composed of species of Metrosideros, especially M. polymorpha (Uchida et al. 2006). In April 2005, a rust fungus (Puccinia psidii Winter), a highly damaging pathogen in myrtaceous hosts in South America, was found on plants of Metrosideros spp. in Hawaii, and this rust pathogen is considered a threat to Hawaiian forest ecosystems (Uchida et al. 2006). Subsequently, half-sib families of Hawaiian ohia seeds were germinated and grown in Brazil to assess the genetic resistance to Brazilian strains of $P$. psidii. However, during a routine inspection at the nursery, seedlings of M. polymorpha showing symptoms of leaf spots, defoliation, young leaf wilt and seedling death were recorded (Fig. 2). In addition, stem necrosis and girdling with root rot were observed. Seedlings with the above disease symptoms kept in a moist chamber showed intense sporulation of a Calonectria sp. on the lesions. Thus, the objective of this study was to characterize the causal agent of this disease through a combination of morphological and molecular data and pathogenicity tests.

\section{Material and methods}

\subsection{Sampling and fungal isolation}

Samples of infected plants of M. polymorpha, containing round, purplish leaf spots, and stem cankers and root rot, were collected in the Forest Nursery at the Universidade Federal de Viçosa.

The samples were kept in a moist chamber at $26^{\circ} \mathrm{C}$ for $48 \mathrm{~h}$. After incubation, single conidial cultures of the Calonectria sp. were obtained on malt extract agar (MEA) at $26^{\circ} \mathrm{C}$ for 10 days. Three selected isolates (LPF 101, LPF 103 and LPF 104) used in this study were deposited at CBS Fungal Biodiversity Institute in the Netherlands (CBS), and nomenclatural data were submitted to MycoBank (Crous et al. 2004b).

\subsection{DNA extraction, amplification and purification}

Mycelia of the respective isolates were scraped from colonized MEA plates and placed separately in 2-ml-microtubes for genomic DNA extraction using the Wizard ${ }^{\circledR}$ Genomic DNA Purification (Promega Corporation, WI, USA) kit. For PCR, the DreamTaq $^{\text {TM }}$ Master Mix (MBI Fermentas, Vilnius, Lithuania) was used, following the manufacturer's protocol.

Four loci, including fragments of $\beta$-tubulin (TUB2), histone H3 (HIS3), elongation factor (tef-1 $\alpha$ ) and calmodulin (CAL) gene regions were amplified using the primers T1 (O’Donnell and Cigelnik 1997) and CYLTUB1R (Crous et al. 2004a) for 


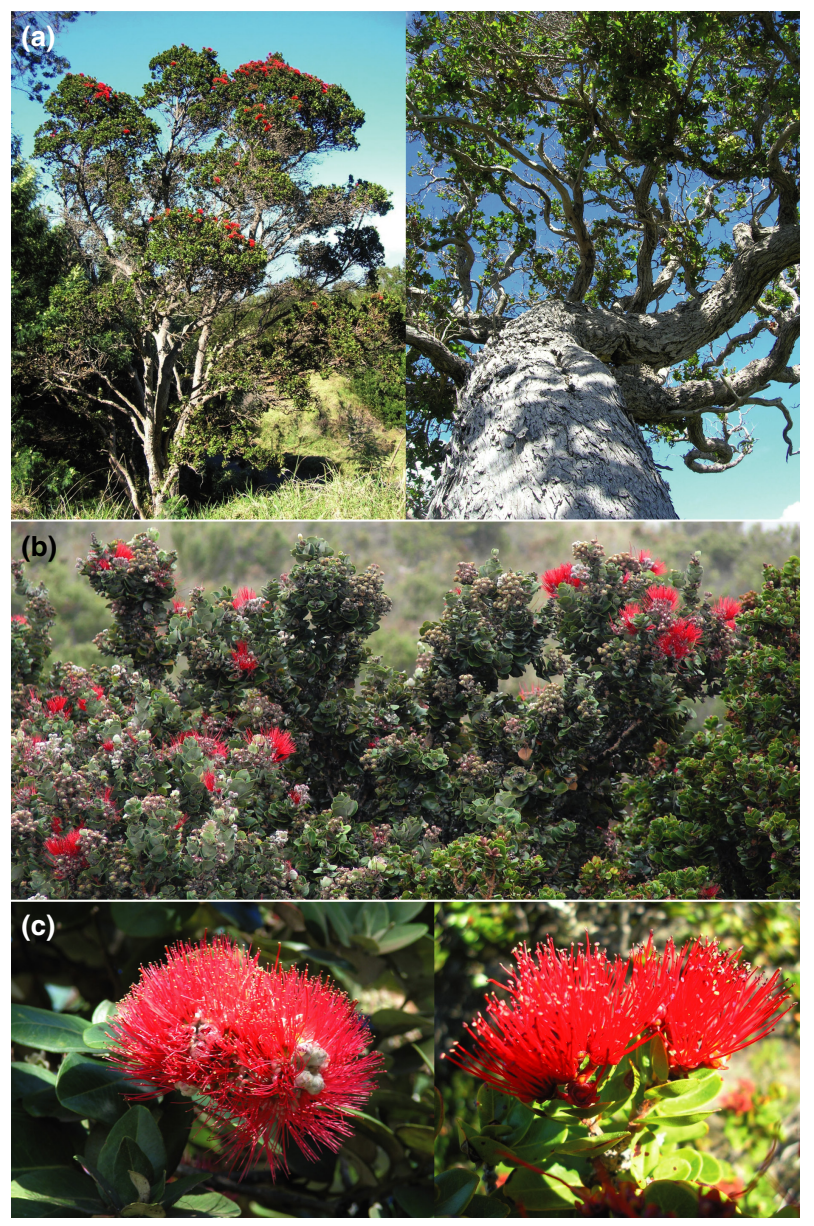

Fig. 1. Meterosideros polymopha in natural stands: (a) Adult trees; (b) Flowering plants; (c) Typical red flowers. (Photos: Forest \& Kim Starr, Starr Environmental, Bugwood.org).

TUB2, CYLH3F and CYLH3R (Crous et al. 2004a) for HIS3, EF1-728F (O'Donnell et al. 1998) and EF-2 (Carbone and Kohn 1999) for TEF-1 $\alpha$ and CAL-228F and CAL-737R (Carbone and Kohn 1999) for CAL. Amplification was performed with an initial denaturing at $96^{\circ} \mathrm{C}$ for $5 \mathrm{~min}$ followed by 35 cycles of denaturation at $96^{\circ} \mathrm{C}$ for $30 \mathrm{~s}$, annealing at $52^{\circ} \mathrm{C}$ for $30 \mathrm{~s}$, extension initial $72^{\circ} \mathrm{C}$ for $1 \mathrm{~min}$ and $4 \mathrm{~min}$ final extension at $72^{\circ} \mathrm{C}$. The PCR product was visualized on a $2 \%$ agarose gel, to determine fragment size and purity. PCR products were purified with an ExoSAP-IT ${ }^{\circledR}$ kit, according to the manufacturer's recommended protocol ( $2 \mu \mathrm{l}$ reagent per $5 \mu \mathrm{l}$ amplified DNA product) and incubated in a thermal cycler for 15 min at $37^{\circ} \mathrm{C}$ followed by an additional incubation for $15 \mathrm{~min}$ at $80^{\circ} \mathrm{C}$.

\subsection{Sequencing and phylogenetic analysis}

Sequencing was performed at the Laboratory of Genomics in the Institute of Biotechnology Applied to Agriculture (BIOAGRO) at the Universidade Federal de Viçosa, Brazil. Sequences quality was checked by means of Sequence Scanner software v. 1.0 (Applied Biosystems, Foster City, CA, USA) and edited using the software package SeqMan from DNAStar Inc. (Madison, WI, USA, www.DNASTAR.com) All sequences were manually corrected, and the arrangement of nucleotides in ambiguous positions was corrected using the sequences of primers in the forward and reverse directions. New sequences derived from this study were deposited in GenBank (http://www.ncbi.nlm.nih.gov/genbank), and other sequences used in phylogenetic analysis were obtained from GenBank (Table 1).

Consensus regions were compared in the GenBank database using the Mega BLAST program. Based on the results of the BLAST, new sequences were added to the alignment of Lombard et al. (2011). All sequences were assembled in the MAFFT v. 6 online version (http://mafft.cbrc.jp/alignment/server/) (Katoh and Toh 2010), and aligned sequences were then manually corrected when necessary using MEGA v. 5 (Tempe, AZ, USA) (Tamura et al. 2011). Spaces (gaps) (insertions/deletions) were treated as absent.

PAUP (Phylogenetic Analysis Using Parsimony, v. 4.0b10; Sunderland, MA, USA; Swofford 2002) was used to analyse the DNA sequence data sets. A partition homogeneity test (Farris et al. 1994) and a 70\% reciprocal bootstrap method (Gueidan et al. 2007) were applied to determine whether the data sets were consistent and combinable. Phylogenetic relationships 


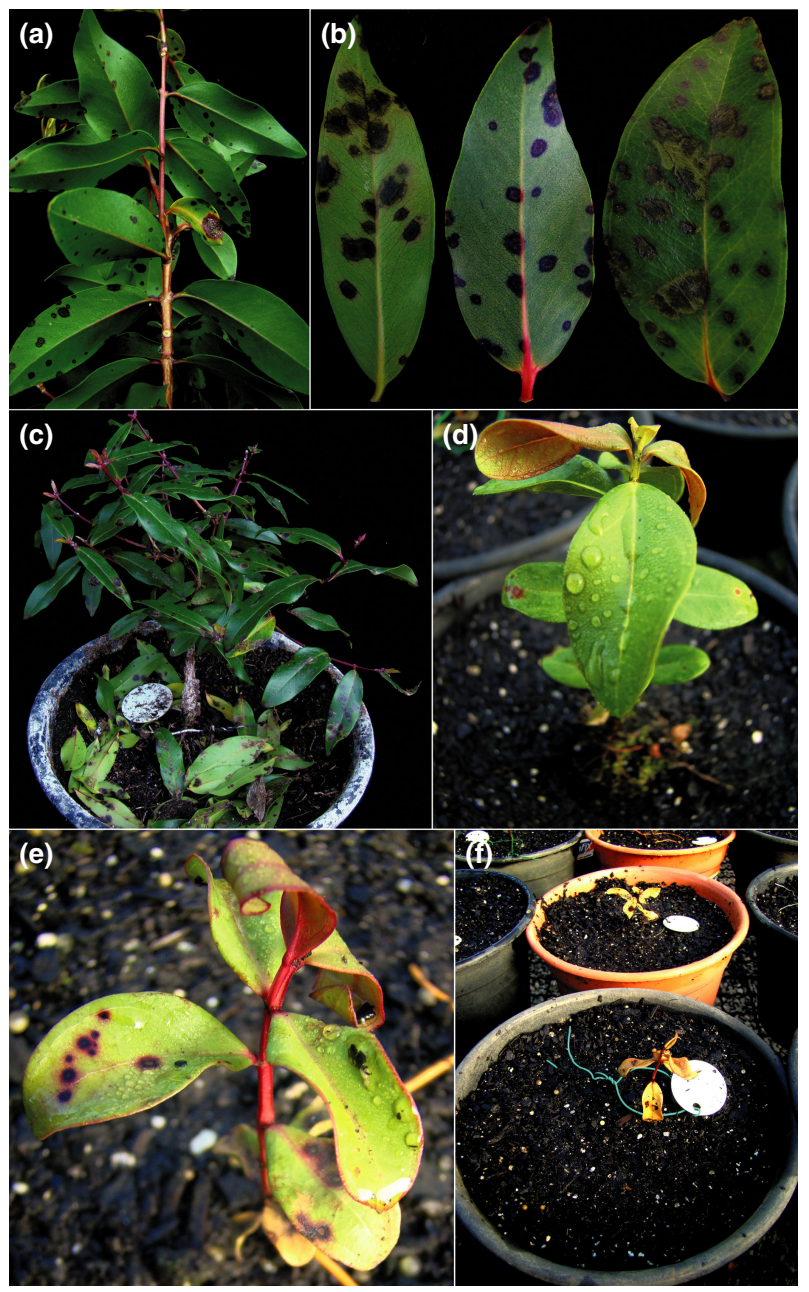

Fig. 2. Incidence of Calonectria metrosideri on seedlings of Metrosideros polymorpha in nursery. a-b: Leafspots; c-Defoliation; d-e: Wilting ofyoung leave on seedlings; f: Dead seedlings.

were estimated by heuristic searches based on 1000 random addition sequences and tree bisection-reconnection, with the branch swapping option set on 'best trees' only. All characters were weighed equally, and alignment gaps were treated as missing data. Measures calculated for parsimony included tree length (TL), consistency index (CI), retention index (RI) and rescaled consistence index (RC). Bootstrap analyses (Hillis and Bull 1993) were based on 1000 replications.

Analysis of Bayesian inference (BI) was performed using the algorithm of Markov chain Monte Carlo (MCMC), and the model of nucleotide substitution used was determined using the MrModeltest v. 2.3 (Posada and Crandall 1998). The models were estimated separately for each gene region. The likelihood values were calculated, and the model was selected according to Akaike information criterion (AIC). BI analysis was completed with MrBayes v. 3.1 .1 (Ronquist and Heulsenbeck 2003) with 10 million random generations. Trees were sampled at every 1000 generations, resulting in 10000 trees. The first 2500 trees were discarded from the analysis. The posterior likelihood values (Rannala and Yang 1996) were determined using the consensus tree. The convergence of the log likelihood was analysed using the software TRACER v. 1.4.1 (Auckland, New Zealand; Rambaut \& Drummond 2009), and no indication of lack of convergence was detected. Calonectria colombiensis Crous and Calonectria chinensis (Crous) L. Lombard, M.J. Wingf. \& Crous were used as outgroups in the analysis.

\subsection{Morphological characterization}

Single conidial cultures were grown on synthetic nutrient poor agar (SNA) (Nirenburg 1981) at $26^{\circ} \mathrm{C}$, following the protocols set for Calonectria by Lombard et al. $(2009,2010 \mathrm{~b}, \mathrm{c})$. After 7 days of incubation, the morphological characteristics were determined by mounting fungal structures in clear lactic acid, and 30 measurements at $\times 1000$ magnification were determined for each isolate using a Zeiss Axioscope 2 microscope (Jena, Germany) with differential interference contrast (DIC) illumination. The 95\% confidence levels were determined, and extremes of conidial measurements are given in parentheses. For other structures, only extremes are presented. 
Table 1. Accession numbers, Calonectria species, gene regions sequenced of Calonectria spp. and host/substrate columns.

\begin{tabular}{|c|c|c|c|c|c|c|}
\hline \multirow[b]{2}{*}{ Isolates } & \multirow[b]{2}{*}{ Species $^{1}$} & \multicolumn{4}{|c|}{ GenBank accession $n r^{2}$} & \multirow[b]{2}{*}{ Host/substrate } \\
\hline & & $\begin{array}{c}\beta-\text { tubulin } \\
\text { (TUB2) }\end{array}$ & $\begin{array}{l}\text { Histone } 3 \\
\text { (HIS3) }\end{array}$ & $\begin{array}{c}\text { Elongation } \\
\text { factor }(\text { tef- } 1 \alpha)\end{array}$ & Calmodulin $(C A L)$ & \\
\hline CBS 230.30 & C. brasiliensis & GQ267241 & GQ267259 & GQ267328 & GQ267421 & Eucalyptus sp. \\
\hline CBS 114257 & C. brasiliensis & GQ267242 & GQ267260 & GQ267329 & GQ267422 & Leaf litter \\
\hline CBS 123693 & C. cerciana & FJ918510 & FJ918528 & FJ918559 & GQ267369 & E. grandis $\times$ urophylla \\
\hline CBS 123695 & C. cerciana & FJ918511 & FJ918529 & FJ918560 & GQ267370 & E. grandis $\times$ urophylla \\
\hline CBS 112744 & C. chinensis & AY725618 & AY725660 & AY725709 & AY725746 & Soil \\
\hline CBS 115127 & C. colombiana & FJ972423 & FJ972442 & FJ972492 & GQ267455 & Soil \\
\hline CBS 115638 & C. colombiana & FJ972422 & FJ972441 & FJ972491 & GQ267456 & Soil \\
\hline CBS 112220 & C. colombiensis & GQ267207 & AY725662 & AY725711 & AY725748 & Soil \\
\hline CBS 111870 & C. hawksworthii & AF333407 & DQ190649 & FJ918558 & GQ267386 & Nelumbo nucifera \\
\hline CBS 114558 & C. insularis & AF210861 & FJ918526 & FJ918556 & GQ267389 & Soil \\
\hline CBS 114559 & C. insularis & AF210862 & FJ918525 & FJ918555 & GQ267390 & Soil \\
\hline CBS 109166 & C. leucothoёs & FJ918508 & FJ918523 & FJ918553 & GQ267392 & Leucothoё axillaris \\
\hline CBS 110918 & C. mexicana & AF210863 & FJ972460 & FJ972526 & GQ267396 & Soil \\
\hline CBS 1303533 & C. mexicana & JN607280 & JN607265 & JN607295 & - & Dodonaea viscosa \\
\hline CBS 110666 & C. morganii & FJ918509 & FJ918527 & FJ918557 & GQ267423 & Ilex vomitoria \\
\hline CBS 119669 & C. morganii & DQ521599 & DQ521601 & GQ421796 & - & Pistacia lentiscus \\
\hline CMW 5683 & C. pauciramosa & FJ918514 & FJ918531 & FJ918565 & GQ267405 & E. grandis \\
\hline CPC 416 & C. pauciramosa & FJ918515 & FJ918532 & FJ918566 & GQ267404 & E. grandis \\
\hline CBS 123402 & C. polizzii & FJ972419 & FJ972438 & FJ972488 & - & Arbutus unedo \\
\hline CBS 125270 & C. polizzii & FJ972417 & FJ972436 & FJ972486 & GQ267461 & Callistemon citrinus \\
\hline CBS 1303513 & C. polizzii & JN607270 & JN607255 & JN607285 & - & Myrtus communis \\
\hline CBS 1303523 & C. polizzii & JN607275 & JN607260 & JN607290 & - & Metrosideros thomasii \\
\hline DISTEF-TMC2 & C. polizzii & JN607269 & JN607254 & JN607284 & - & Myrtus communis \\
\hline DISTEF-TMEA1 & C. polizzii & JN607272 & JN607257 & JN607287 & - & $\begin{array}{l}\text { Metrosideros excelsa } \\
\text { cv. Aurea }\end{array}$ \\
\hline DISTEF-TMN3 & C. polizzii & JN607274 & JN607259 & JN607289 & - & Metrosideros sp. \\
\hline CBS 1303543 & C. pseudomexicana & JN607281 & JN607266 & JN607496 & - & Callistemon sp. (rouge) \\
\hline CBS 1303553 & C. pseudomexicana & JN607282 & JN607267 & JN607497 & - & Callistemon sp. (rouge) \\
\hline DISTEF-TCROU4 & C. pseudomexicana & JN607283 & JN607268 & JN607498 & - & Callistemon sp. (rouge) \\
\hline CBS 125256 & C. pseudoscoparia & GQ267228 & GQ267277 & GQ267348 & GQ267440 & E. grandis \\
\hline CBS 125257 & C. pseudoscoparia & GQ267229 & GQ267278 & GQ267349 & GQ267441 & E. grandis \\
\hline CPC 1675 & C. scoparia & FJ972426 & FJ972476 & FJ972525 & GQ267367 & Eucalyptus sp. \\
\hline СРC 1679 & C. scoparia & GQ421779 & GQ267246 & GQ267298 & GQ267368 & Eucalyptus sp. \\
\hline CBS 133603 & $\begin{array}{l}\text { C. metrosideri } \\
\text { sp. nov }\end{array}$ & КС294313 & КС294307 & KC294310 & KC294304 & $\begin{array}{l}\text { Metrosideros } \\
\text { polymorpha (leaf) }\end{array}$ \\
\hline CBS 133604 & $\begin{array}{l}\text { C. metrosideri } \\
\text { sp. nov }\end{array}$ & КС294314 & КС294308 & КC294311 & KC294305 & $\begin{array}{l}\text { Metrosideros } \\
\text { polymorpha (leaf) }\end{array}$ \\
\hline CBS 133605 & $\begin{array}{l}\text { C. metrosideri } \\
\text { sp. nov }\end{array}$ & КС294315 & КС294309 & КС294312 & КС294306 & $\begin{array}{l}\text { Metrosideros } \\
\text { polymorpha (root) }\end{array}$ \\
\hline CBS 112689 & C. spathulata & AF308463 & FJ918524 & FJ918554 & GQ267426 & E. viminalis \\
\hline CBS 555.92 & C. spathulata & GQ267215 & GQ267261 & GQ267331 & GQ267427 & Araucaria angustifolia \\
\hline CBS 125248 & C. sulawesiensis & GQ267223 & GQ267272 & GQ267343 & GQ267435 & Eucalyptus sp. \\
\hline CBS 125253 & C. sulawesiensis & GQ267220 & GQ267269 & GQ267340 & GQ267432 & Eucalyptus sp. \\
\hline CBS 1303563 & C. tunisiana & JN607277 & JN607262 & JN607292 & - & Callistemon sp. (rouge) \\
\hline CBS 1303573 & C. tunisiana & JN607276 & JN607261 & JN607291 & - & Callistemon laevis \\
\hline DISTEF-TCV1 & C. tunisiana & JN607278 & JN607263 & JN607293 & - & Callistemon viminalis \\
\hline DISTEF-TCROS4 & C. tunisiana & JN607279 & JN607264 & JN607294 & - & Callistemon sp. (rosè) \\
\hline DISTEF-TME1 & C. tunisiana & JN607271 & JN607256 & JN607286 & - & Metrosideros excelsa \\
\hline DISTEF-TMN1 & C. tunisiana & JN607273 & JN607258 & JN607288 & - & Metrosideros sp. \\
\hline CBS 112691 & C. variabilis & GQ267240 & GQ267264 & GQ267335 & GQ267458 & Eucalyptus sp. \\
\hline CBS 114677 & C. variabilis & AF333424 & GQ267263 & GQ267334 & GQ267457 & Eucalyptus sp. \\
\hline CMW 9188 & C. zuluensis & FJ972414 & FJ972433 & FJ972483 & GQ267459 & Eucalyptus sp. \\
\hline CMW 9896 & C. zuluensis & FJ972415 & FJ972434 & FJ972484 & GQ267460 & Eucalyptus sp. \\
\hline
\end{tabular}




\subsection{Pathogenicity}

Because the undescribed Calonectria species was isolated from infected M. polymorpha, this plant was selected to confirm

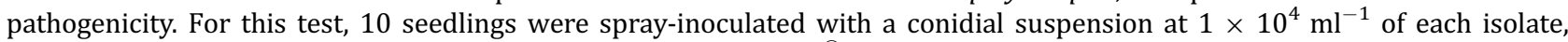
as described by Graça et al. (2009). Potting medium (Mec Plant ${ }^{\circledR}$ substrate, Telêmaco Borba, Paraná, Brazil) supporting 10 healthy seedlings was also infested by adding $30 \mathrm{ml}$ of the same conidial suspension in each of the four holes made around each plant. Five plants treated with distilled water served as control. The development of symptoms was monitored daily for 10 days.

\subsection{Source of inoculum}

To determine the inoculum source of inoculum, samples of irrigation water and samples of unused/ used substrate were tested for the presence of the pathogen using the castor bean leaf bio-baiting method (Gonçalves et al. 2001).

\subsection{Disease progress}

Disease progress was evaluated on plants growing at the original nursery where the disease was discovered by counting the number of wilted or dead plants at biweekly intervals from April to July, 2010.

\section{Results}

\subsection{Phylogenetic analysis}

Amplicons of approximately 450 bases for HIS3 and 500 bases each for TUB2, TEF-1 $\alpha$ and CAL were generated. Based on preliminary tef-1 $\alpha$ sequence analyses with 49 taxa including outgroups (Fig. 3), the multigene analysis was performed with closely related species, which belong to the Calonectria scoparia complex.

The combined sequence analysis was performed with 18 taxa, including outgroups. Comparing the tree topologies of the $70 \%$ reciprocal bootstrap trees indicated no conflicts. Subsequently, the data sets were combined, and this resulted in a data set consisting of 1899 characters including gaps. Of these, 1634 were constant and parsimony uninformative, and

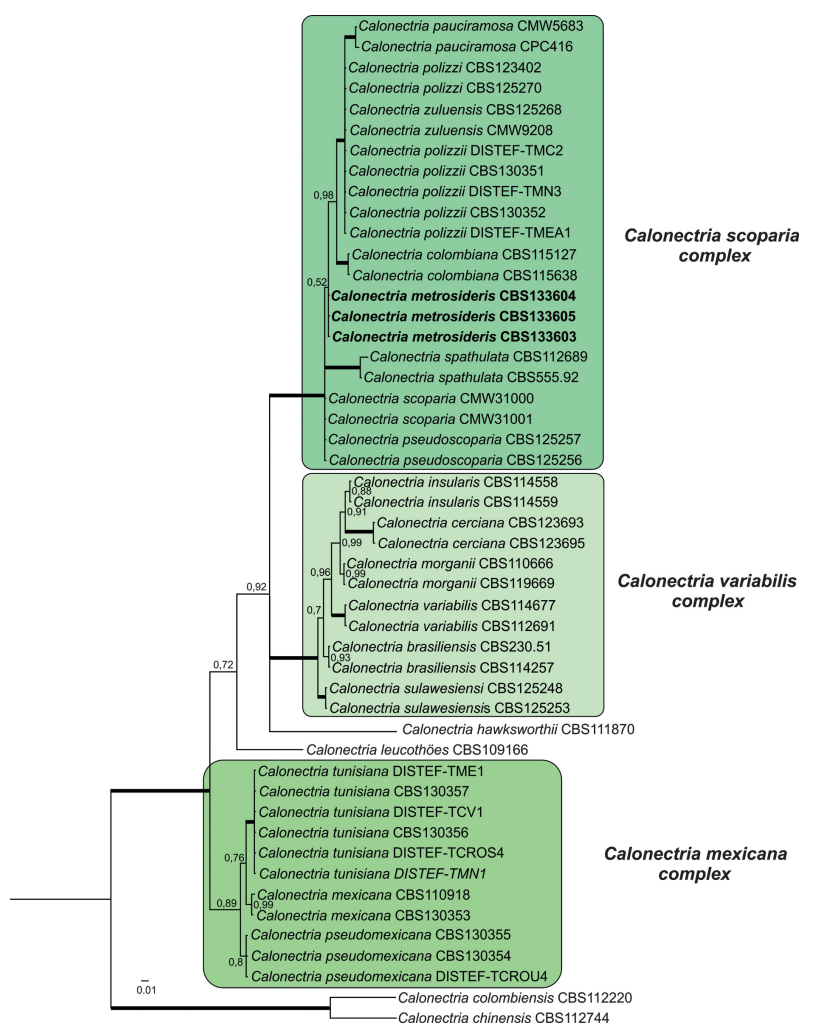

Fig. 3. Phylogenetic tree obtained by Bayesian inference using sequences oftranslation elongation factor. 1a sequence alignments ofthe Calonectria isolates. The bold lines indicate posterior probability values of 1.00 . The tree was rooted to $C$ chinensis (CBS 112744 ) and C. colombiensis (CBS 112220). Isolates in bold were obtained during the survey. 
295 were parsimony informative. Analysis of the 295 parsimony informative characters yielded four equally most parsimonious trees $(\mathrm{TL}=561, \mathrm{CI}=0.904, \mathrm{RI}=0.911, \mathrm{RC}=0.823)$. Evolution models $\mathrm{HKY}+\mathrm{I}$ for $\mathrm{TUB} 2$ and $\mathrm{CAL}$, and $\mathrm{GTR}+\mathrm{G}$ for HIS3 and tef- $1 \alpha$ were selected and incorporated into the Bayesian analysis.

The preliminary tree performed with tef- $1 \alpha$ can distinguish Calonectria scoparia complex from the other Calonectria complexes (C. variabilis and C. mexicana); however, it is not useful for separating $C$. metrosideri from other species within the C. scoparia complex (Fig. 3). The newly described $C$. metrosideri can be distinguished from other Calonectria spp. within the C. scoparia complex using an additional three loci (HIS3, TUB2 and CAL). The multigene analysis formed a distinct and well-supported clade close to but distinct from $C$. pseudoscoparia and C. scoparia (Fig. 4).

\subsection{Taxonomy}

Based on the DNA sequence data and morphological features of the anamorph, we conclude that the Calonectria isolates from $M$. polymorpha represent an undescribed new species, described below as follows:

Calonectria metrosideri R.F. Alfenas, O.L. Pereira, P.W Crous \& A.C. Alfenas, sp. nov. MycoBank MB 802511 (Fig. 5).

Etymology: In reference to the genus Metrosideros, from which the fungus was isolated.

Hosts: Metrosideros polymorpha.

Distribution: Brazil.

Conidiophores containing a stipe bearing penicillate suites of fertile branches, stipe extension and terminal vesicle; stipe septate, hyaline, smooth, 40-105 × 4-7 $\mu \mathrm{m}$; stipe extensions septate, straight to flexuous, 90-170 $\mu \mathrm{m}$ long, 2-4 $\mu \mathrm{m}$ wide at the apical septum, terminating in spathulate to obpyriform vesicles, 5-9 $\mu \mathrm{m}$ diam (abnormal bifurcate vesicles frequently observed). Conidiogenous apparatus 40-65 $\mu \mathrm{m}$ long, 60-75 $\mu \mathrm{m}$ wide; primary branches aseptate, 18-30 $\times 4-5 \mu \mathrm{m}$; secondary branches aseptate, 18-22 × 3-4 $\mu \mathrm{m}$; tertiary and additional branches $(-4)$, aseptate, 8-15 $\times 3-4 \mu \mathrm{m}$, each terminal branch producing 2-6 phialides; phialides elongate doliiform to reniform, hyaline, aseptate, 8-11 $\times 3-4 \mu \mathrm{m}$; apex with minute periclinal thickening and inconspicuous collarette. Macroconidia cylindrical, rounded at both ends, straight, (40-)44-46 $(-51) \times 3-5 \mu \mathrm{m}(\mathrm{av} .=45 \times 4 \mu \mathrm{m}), 1$-septate, lacking a visible abscission scar, held in parallel cylindrical clusters by colourless slime. Mega- and microconidia were not seen observed.

Notes: Calonectria metrosideri (conidia av. $45 \times 4 \mu \mathrm{m}$ ) can be distinguished from C. scoparia (conidia av. $60 \times 4.5 \mu \mathrm{m}$ ) and $C$. pseudoscoparia (conidia av. $48 \times 4 \mu \mathrm{m}$ ) based on smaller macroconidia and on being phylogenetically distinct. Mating tests resulted in no successful matings, suggesting that the fungus either is heterothallic, with no compatible tester strains found, or has lost the ability for sexual mating.

Culture characteristics: Rapid growth $50-55 \mathrm{~mm}$ diam after 10 days at $25^{\circ} \mathrm{C}$ on Malt Extract Agar (MEA), aerial mycelial and sporulation sparse; chlamydospores forming brown, thick-walled microsclerotia.

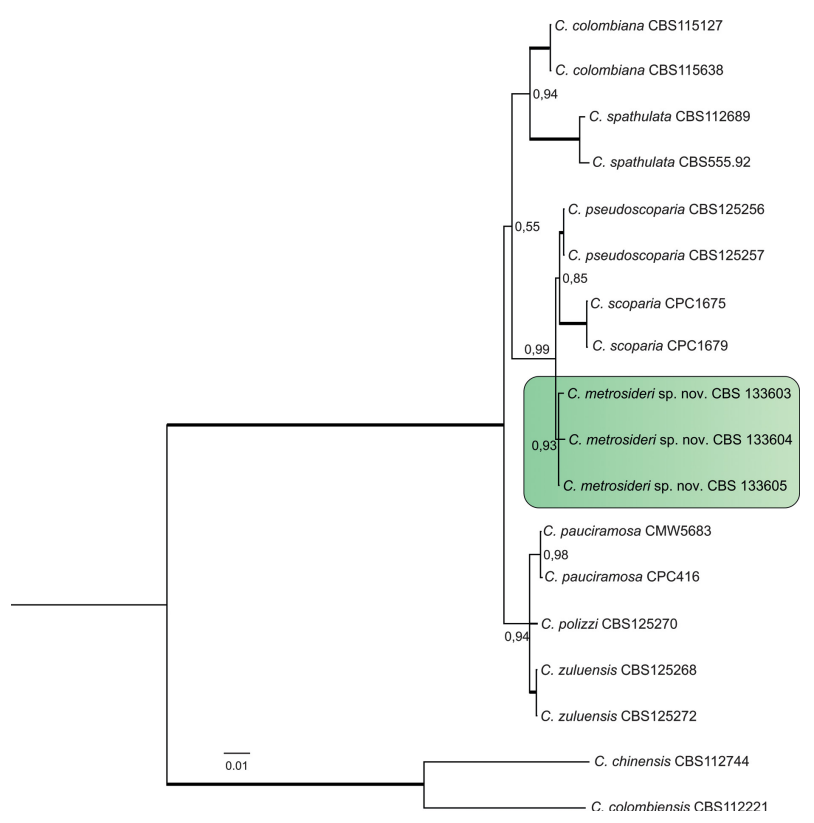

Fig. 4. Phylogenetic tree obtained by Bayesian inference using combined sequences of p-tubulin, histone H3, translation elongation factor 1a and calmodulin sequence alignments of Calonectria isolates. The bold lines indicate posterior probability values of 1.00 . The tree was rooted to C. chinensis (CBS 112744) and C. colombiensis (CBS 112220). Isolates in bold were obtained during the survey. 


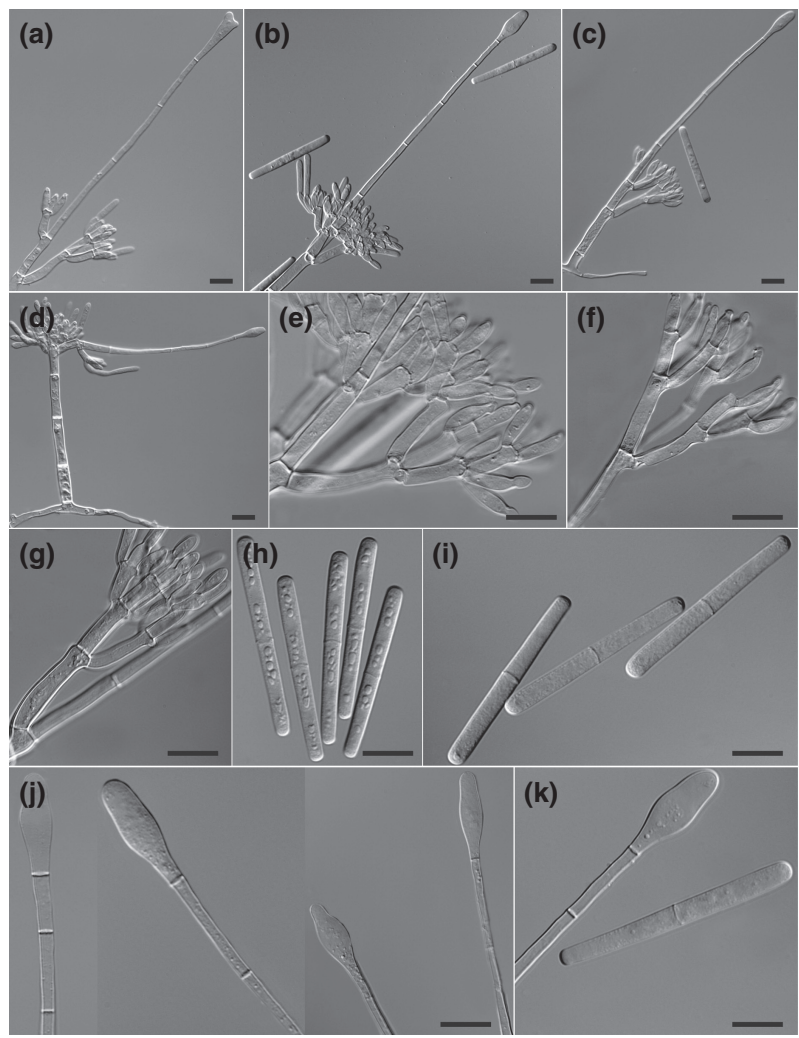

Fig. 5. Morphological characteristics of Calonectria metrosideri. a: Macroconidiophores containing an abnormal bifurcate vesicles; b-d: Macroconidiophores containing typical vesicles; e-g: Three branched conidiophores; $\mathrm{h}-\mathrm{i}$ : 1 -septate macroconidia and $\mathrm{j}-\mathrm{k}$ : Spathulate to obpyriform vesicles. Scale bars $=10 \mu \mathrm{m}$.

\subsection{Pathogenicity}

As observed in the nursery under natural infection, spray-inoculated plants showed leaf spots, and seedlings grown in pathogen-infested substrate exhibited root rot and wilt symptoms and eventually died. Intense defoliation was also found with spray-inoculated plants.

\subsection{Source of inoculum}

Irrigation water and potting medium were Calonectria free. However, used substrate produced pathogen colonization in $6.3 \%$ of castor bean leaf baits. These results indicate that neither the irrigation water nor the substrate was the primary inoculum source of the fungus.

\subsection{Disease progress}

The number of infected plants of $M$. polymorpha and $M$. tremuloides increased significantly over time, reaching up 71 and $34 \%$ of diseased seedlings, respectively, in about four months. Higher disease levels occurred on Metrosideros polymorpha compared with $M$. tremuloides (Fig. 6).

\section{Discussion}

To characterize the causal agent of the Metrosideros disease, isolates of a Calonectria sp. obtained from infected plants were identified as a phylogenetically undescribed species. This is described here as Calonectria metrosideri sp. nov., which is closely related to the C. scoparia complex (Schoch et al. 1999, 2001). This complex includes C. pauciramosa C.L. Schoch \& Crous, C. scoparia Peerally, C. mexicana CL Schoch \& Crous, C. spathulata El-Gholl, Kimbr., E.L. Barnard, Alfieri \& Schoult and C. insularis Schoch \& Crous (Schoch et al. 1999). More recently, Lombard et al. (2010b, 2011) added a further five species to this complex, namely C. zuluensis Lombard, Crous \& MJ Wingf., C. polizzi Lombard, Crous \& MJ Wingf., C. colombiana L. Lombard, Crous \& MJ Wingf., C. pseudomexicana L. Lombard, G. Polizzi \& Crous and C. tunisiana L. Lombard, G. Polizzi \& Crous. Species of $C$. scoparia sensu lato are characterized by having obpyriform (= as spathulate) to ellipsoidal vesicles, as well as uniseptate conidia (Schoch et al. 1999). 


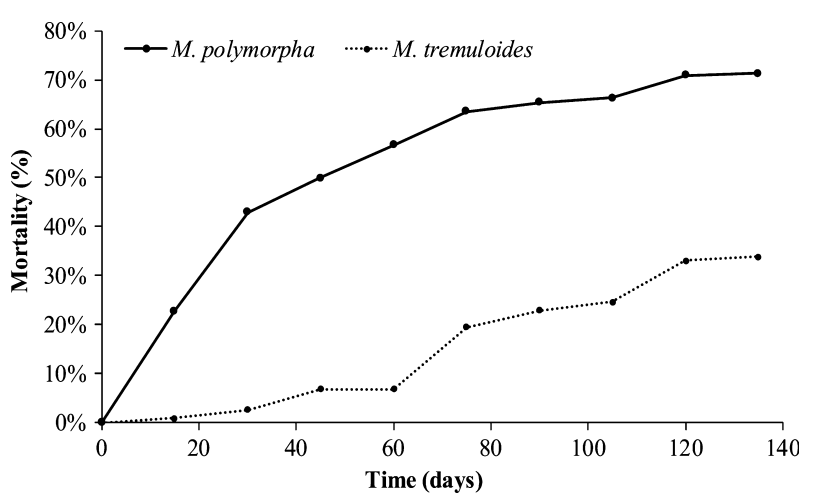

Fig. 6. Seedling mortality of Meterosideros polymorpha and M. tremuloides caused by Calonectria metrosideri in a forest nursery with temperatures of $25^{\circ} \mathrm{C}-30^{\circ} \mathrm{C}$ and irrigation daily.

Although $C$. metrosideri is phylogenetically and morphologically close to $C$. scoparia and $C$. pseudoscoparia, it grouped in a well-supported, distinct clade. Furthermore, it also has smaller conidia than the latter two species. Currently, identification of species based on phylogenetic inference has shown that many species of plant pathogens represent a species complex (Crous and Groenewald 2005; Hyde et al. 2010). The problem is that sometimes the phylogenetic species concept is not correlated with morphology, and the boundaries of separation between taxa remain unclear. In some cases, the separation of two or more groups of isolates as distinct taxa may occur, but in fact, they could belong to the same species (Summerell et al. 2010). Therefore, before assigning isolates to a new species, it is necessary to find robust differences by employing additional techniques (Summerell et al. 2010), as done in the present work.

Recent studies describing novel species of Calonectria have employed a combination of the phylogenetic and morphological species concepts (Lombard et al. 2010a,c). The difficulty of only adopting the biological species concept in Calonectria is that some isolates of different phylogenetically related species (C. hawksworthii, C. insulare and C. scoparium) can interbreed and produce fertile progeny.

Recently, Lombard et al. (2011) also described two new species of Calonectria from Metrosideros sp. (C. pseudomexicana and $C$. tunisiana) and underlined the importance of phytosanitary and quarantine measures, to prevent the introduction of these species into Hawaii. Calonectria metrosideri differs phylogenetically and morphologically from C. pseudomexicana and C. tunisiana, which also have wider conidia and broadly ellipsoidal vesicles.

Although the present description is based on characteristics of the anamorph (Cylindrocladium), the new species from ohia is named in the genus Calonectria, because all species of Cylindrocladium are phylogenetically connected to Calonectria. Moreover, the oldest name prevails (Crous 2002; Crous et al. 2004a, 2006; Schoch et al. 1999) and the use of Calonectria is being adopted in proposals of new species, even when the sexual state is not observed (Lombard et al. 2010a, 2011; Wingfield et al. 2012).

All three isolates (CBS133603, CBS133604 and CBS133605) of C. metrosideri tested were pathogenic and induced disease symptoms in seedlings of $M$. polymorpha similar to those observed in the nursery under natural infection. However, wilted and dead plants were only observed when the potting medium was infested with inoculum of the pathogen. In this case, the fungus infects the root system and induces seedling wilt. Species of Calonectria are soil-borne pathogens (Crous 2002). In a eucalypt cutting nursery, Calonectria spp. and other pathogens are spread and infect healthy plants mainly from inoculum in contaminated water (Mafia et al. 2008), infested substrate, tubes and scissors, as well as infected shoots used to make cuttings (Alfenas et al. 2009). In this study, we confirmed that the irrigation water and the potting medium used for growing ohia plants were pathogen inoculum free at the time of testing. Therefore, contaminated pots were probably the primary inoculum source of $C$. metrosideri on ohia. This conclusion is based on the fact that once pots were subjected to a hot water treatment $\left(80^{\circ} \mathrm{C} \mathrm{min}^{-1}\right)$ (Alfenas et al. 2009), the disease was successfully controlled.

As observed among and within species of Eucalyptus susceptible to leaf blight caused by Calonectria pteridis (Alfenas et al. 2009; Zarpelon et al. 2011), indications of differences in resistance to C. metrosideri infection were also observed between M. polymorpha and M. tremuloides. However, in nurseries, cultural practices aiming to eradicate the sources of inocula and to reduce the environmental conditions favourable to infection are the most important forms of disease control, whereas breeding for resistance is more applicable to the establishment of plantations or replacement of forest trees.

The description of $C$. metrosideri sp. nov. represents a novel species for Brazil. The rapid progress of this disease indicates the high aggressiveness of this pathogen and the urgent need for control methods, especially cultural practices, to minimize losses from the disease in forest nurseries.

\section{Acknowledgements}

We thank the Department of Plant Pathology of Universidade Federal de Viçosa and CBS-KNAW Fungal Biodiversity Centre for financial and technical support to undertake this study. This work was supported by CAPES (Coordenação de Aperfeiçoamento de Pessoal de Nível Superior), CNPq (Conselho Nacional de Desenvolvimento Científico e Tecnológico) and FAPEMIG (Fundação de Amparo à Pesquisa de 
Minas Gerais). We are grateful to Phil Cannon (USDA Forest Service, Forest Health Protection, Region 5) and the Rob Hauff (Hawaii Dept. of Forestry and Wildlife) for collaborative arrangements and supplying the ohia seed for this study. The first author is also grateful to Dr. Lorenzo Lombard, Dr. J. Z. Groenewald and Danilo Batista Pinho, for advice regarding DNA sequences analyses.

\section{References}

Alfenas, A. C.; Zauza, E. A. V.; Mafia, R. G.; Assis, T. F., 2009. Clonagem e Doenças do Eucalipto, 2nd edn. Viçosa, MG, Brazil: Editora UFV.

Carbone, I.; Kohn, L. M., 1999: A method for designing primer sets for speciation studies in filamentous ascomycetes. Mycologia 91, 553556.

Cordell, S.; Goldstein, G.; Mueller-Dombois, D.; Webb, D.; Vitousek, P. M., 1998: Physiological and morphological variation in Metrosideros polymorpha, a dominant Hawaiian tree species, along an altitudinal gradient: the role of phenotypic plasticity. Oecologia 113, 188-196.

Crous, P. W., 2002. Taxonomy and pathology of Cylindrocladium (Calonectria) and allied genera. St. Paul, Minnesota: APS Press.

Crous, P. W.; Groenewald, J. Z., 2005: Hosts, species and genotypes: opinions versus data. Australas. Plant Pathol. 34, 463-470.

Crous, P. W.; Groenewald, J. Z.; Risede, J.-M.; Simoneau, P.; Hywel-Jones, N. L., 2004a: Calonectria species and their Cylindrocladium anamorphs: species with sphaeropedunculate vesicles. Stud. Mycol. 50, 415-430.

Crous, P. W.; Gams, W.; Stalpers, J. A.; Robert, V.; Stegehuis, G., 2004b: MycoBank: an online initiative to launch mycology into the 21st century. Stud. Mycol. 50, 19-22.

Crous, P. W.; Groenewald, J. Z.; Risède, J.-M.; Simoneau, P.; Hyde, K. D., 2006: Calonectria species and their Cylindrocladium anamorphs: species with clavate vesicles. Stud. Mycol. 55, 213-226.

Farris, J. S.; Källersjö, M.; Kluge, A. G.; Bult, C., 1994: Testing significance of incongruence. Cladistics 10, 315-320.

Friday, J. B.; Herbert, D. A., 2006. Metrosideros polymorpha ('ōhi'a lehua). Species Profiles for Pacific Island Agroforestry. p. 1-27.

Gonçalves, R. C.; Alfenas, A. C.; Maffia, L. A.; Crous, P. W., 2001: Evaluation of bioassays to quantify Cylindrocaldium inocula in soil. Mycoscience 42, 261-264.

Graça, R. N.; Alfenas, A. C.; Maffia, L. A.; Titon, M.; Alfenas, R. F.; Lau, D.; Rocabado, J. M. A., 2009: Factors influencing infection of eucalypts by Cylindrocladium pteridis. Plant. Pathol. 58, 971-981.

Gueidan, C.; Roux, C.; Lutzoni, F., 2007: Using multigene phylogeny analysis to assess generic delineation and character evolution in Verrucariaceae (Verrucariales, Ascomycota). Mycol. Res. 111, 1145-1168.

Hillis, D. M.; Bull, J. J., 1993: An empirical test of bootstrapping as a method for assessing confidence in phylogenetic analysis. Syst. Biol. 42, 182-192.

Hyde, K. D.; Chomnunti, P.; Crous, P. W.; Groenewald, J. Z.; Damm, U.; KoKo, T. W.; Shivas, R. G.; Summerell, B. A.; Tan, Y. P., 2010: A case for re-inventory of Australia's plant pathogens. Persoonia 25, 50-60.

Katoh, K.; Toh, H., 2010: Parallelization of the MAFFT multiple sequence alignment program. Bioinformatics 26, 1899-1900.

Lombard, L.; Rodas, C. A.; Crous, P. W.; Wingfeld, B. D.; Wingfeld, M. J., 2009: Cylindrocladium species associated with dying Pinus cuttings. Persoonia 23, 41-47.

Lombard, L.; Crous, P. W.; Wingfield, B. D.; Wingfield, M. J., 2010a: Species concepts in Calonectria (Cylindrocladium). Stud. Mycol. 66, 1-14.

Lombard, L.; Crous, P. W.; Wingfield, B. D.; Wingfield, M. J., 2010b: Multigene phylogeny and mating tests reveal three cryptic species related to Calonectria pauciramosa. Stud. Mycol. 66, 15-30.

Lombard, L.; Crous, P. W.; Wingfield, B. D.; Wingfield, M. J., 2010c: Phylogeny and systematics of the genus Calonectria. Stud. Mycol. 66, 31-69.

Lombard, L.; Polizzi, G.; Guarnaccia, V.; Vitale, A.; Crous, P. W., 2011: Calonectria spp. causing leaf spot, crown and root rot of ornamental plants in Tunisia. Persoonia 27, 73-79.

Mafia, R. G.; Alfenas, A. C.; Ferreira, E. M.; Machado, P. S.; Binoti, D. H. B.; Leite, F. P.; Souza, F. L., 2008: Reuse of untreated irrigation water as a vehicle of inoculum of pathogens in eucalyptus clonal nursery. Tropical Plant Pathology 33, 96-102.

Nirenburg, H. I., 1981: A simplified method for identifying Fusarium spp. occurring on wheat. Can. J. Bot. 59, 1599-1609.

O’Donnell, K.; Cigelnik, E., 1997: Two divergent intragenomic rDNA ITS2 types within a monophyletic lineage of the fungus Fusarium are nonorthologous. Mol. Phylogenet. Evol. 7, 103-116.

O'Donnell, K.; Kistler, H. C.; Cigelnik, E.; Ploetz, R. C., 1998: Multiple evolutionary origins of the fungus causing Panama disease of banana: concordant evidence from nuclear and mitochondrial gene genealogies. Proc. Natl Acad. Sci. USA 95, 2044-2049.

Posada, D.; Crandall, K. A., 1998: Modeltest: testing the model of DNA substitution. Bioinformatics 14, 817-818.

Rannala, B.; Yang, Z., 1996: Probability distribution of molecular evolutionary trees: a new method of phylogenetic inference. J. Mol. Evol. 43, 304-311.

Rambaut, A.; Drummond, A. J., 2009: Tracer v1.5. Available from http://beast.bio.ed.ac.uk/Tracer.

Ronquist, F.; Heulsenbeck, J. P., 2003: MrBayes 3: bayesian phylogenetic inference under mixed models. Bioinformatics 19, $1572-1574$.

Schoch, C. L.; Crous, P. W.; Wingfeld, B. D.; Wingfeld, M. J., 1999: The Cylindrocladium candelabrum species complex includes four distinct mating populations. Mycologia 91, 286-298.

Schoch, C. L.; Crous, P. W.; Wingfeld, B. D.; Wingfeld, M. J., 2001: Phylogeny of Calonectria based on comparisons of $\beta$-tubulin DNA sequences. Mycol. Res. 105, 1045-1052.

Summerell, B. A.; Laurence, M. H.; Liew, E. C. Y.; Leslie, J. F., 2010: Biogeography and phylogeography of Fusarium: a review. Fungal Diversity 43, 3-13.

Swofford, D. L., 2002. PAUP*. Phylogenetic Analysis Using Parsimony (*and other methods). 4.0b10. Computer program. Sunderland, Massachusetts: Sinauer Associates.

Tamura, K.; Peterson, D.; Peterson, N.; Stecher, G.; Nei, M.; Kumar, S., 2011: MEGA5: molecular evolutionary genetics analysis using Maximum Likelihood, Evolutionary Distance, and Maximum Parsimony Methods. Mol. Biol. Evol. 28, 2731-2739.

Uchida, J.; Zhong, S.; Killgore, E., 2006: First Report of a Rust Disease on Ohia Caused by Puccinia psidii in Hawaii. Plant Dis. 90, 524-524.

Wingfield, M. J.; de Beer, Z. W.; Slippers, B.; Wingfield, B. D.; Groenewald, J. Z.; Lombard, L.; Crous, P. W., 2012: One fungus, one name promotes progressive plant pathology. Mol. Plant Pathol. 13, 604-613.

Zarpelon, T. G.; Guimarães, L. M. S.; Coutinho, M. M.; Capua Neto, B.; Faria, D. A.; Grattapaglia, D.; Alfenas, A. C., 2011. QTL associated with resistance to defoliation (Cylindrocladium pteridis) in Eucalyptus spp. In: IUFRO Tree Biotechnology Conference 2011, Porto Seguro. Anais CD-Room IUFRO Tree Biotechnology Conference. p. 79. 